\title{
Sound Shift and Metathesis in Three Pre-School Nasiriya Iraqi Arabic Children: A Case Study
}

\author{
Mohammed Jasim Betti ${ }^{1}$ \& Zainab Kadim Igaab ${ }^{1}$ \\ ${ }^{1}$ Dept. of English, College of Education for Humanities, University of Thiqar, Iraq \\ Correspondence: Mohammed Jasim Betti, Dept. of English, College of Education for Humanities, University of \\ Thiqar, Iraq. E-mail: alseady2@gmail.com and zainabigaab@yahoo.com
}

Received: October 3, 2018 Accepted: November 29, 2018 Online Published: December 29, 2018

doi:10.5539/ijel.v9n1p229 URL: https://doi.org/10.5539/ijel.v9n1p229

\begin{abstract}
This study is a case study which describes the speech of three pre-school Nasiriya Iraqi Arabic children. The data of this study are collected through tape-recording them. Through the analysis, it is concluded that the phonetic processes which exist in the informants' speech include assimilation, elision, gemination, nasalization and tafxiim and the main ones are sound shift and metathesis. It has been noted that the study informants pronounce some consonants which are difficult to be pronounced by other children living in the same city; those consonants are either regularly shifted to in the production of other consonants or as part of ordinary words containing such sounds. Sometimes, more than one process is available in the production of some words. The consonantal changes existing in the informants' speech are many compared with the vocalic ones which are very few.
\end{abstract}

Keywords: phonetic processes, pre-school children, Nasiriya Iraqi Arabic

\section{Introduction}

Nasiriya is a city in Iraq which is located along the banks of the Euphrates River. It is one of the southern cities in Iraq and it is about 225 miles $(370 \mathrm{~km})$ southeast of Baghdad. It is situated near the ruins of the ancient city of Ur. It is regarded as the centre of the Thi-Qar governorate.

The aim of the study is to describe the speech of three preschool children and the characteristic processes accompanying their speech like sound shift, metathesis, elision, assimilation, gemination, nasalization, and tafxiim.

The study hypothesizes the following:

a. Sound shift and metathesis mainly exist in most Nasiriya Iraqi consonants of the informants.

b. The secondary processes occurring in the informants' speech include elision, assimilation, gemination, tafxiim, and nasalization.

This study is limited to investigate the speech of three Nasiriya Iraqi Arabic pre-school children. This description includes both vocalic and consonantal segments.

In analyzing the speech of the two authors' children, we discover that their speech is characteristic of sound shift and other linguistic processes and we assume that they follow some phonetic rules which are specific to them and we tried to list those rules in tables.

\section{Literature Review}

\subsection{Linguistic Description of Acquisition}

Children of 1-2 years produce the first word combination. Then simple and complex sentences are produced when they become 4-6 years old.

Any study concerning the child's language acquisition includes a description and then an explanation for the sound segments produced by the children. The explanation is the uneasy step to deal with because it involves dealing with children not adults. According to Ingram (1987, p. 10), "The value of dairy studies is enormous in providing a database for the field. In some cases, the data are rich to provide the basis for a study and at other cases, the data may be supplemented in that it is used in conjunction with newly collected data to substantiate a point". 
During the process of child language acquisition, there are two principal variables: referentiality and sound change noticeability. Each is of a universal nature. Sound change noticeability deals with the easiness of perceiving some sound changes. There are some sounds which are more noticeable in their changes than others. For instance the changes and addition of the vowels can be noticed more than those of the consonants. This is because when vowels change, syllables are created and then they must receive some degree of stress. So, changing play into playing or come into came can be noticed more than jump into jumped /pt/ (Steinberg, 1991, pp. 154-155).

Greenlee (1980, p. 283) also comments by saying: "many assume that the child is the initiator of sound change". In children's acquisition, nasal consonants are separated from oral ones especially the oral stops at the very early age, and this distinction is among the first consonant contrasts to appear in children's speech. The phonetic basis of nasal stability can be found in the articulatory and acoustic properties of nasals as their production requires simple articulatory requirements and they are acoustically distinct from other classes of consonants (Ibid, $\mathrm{p}$. 288).

Depending on Jackobson's observation (1941), in all languages, children learn sound segments in a relatively fixed order. For example, in English, children tend to acquire /f/ before / $/$ /: three /free/, thumb /fumb/, etc; voiceless stops are acquired before voiced stops. So, $/ \mathrm{p}, \mathrm{t}, \mathrm{k} /$ are expected to be acquired before $/ \mathrm{b}, \mathrm{d}, \mathrm{g} /$. Also, the front consonants like /p, t/ are acquired before the back consonants /k/ (Hyman, 1975, pp. 16-17).

\subsection{Phonology of Iraqi Arabic}

Iraqi Arabic is one variety of Arabic that is used by the Iraqi people: educated and non-educated to communicate with each other. It is like other varieties which have their own phonetic and phonological systems with a number of consonants and vowels (Jasim \& Sharhan, 2013, p. 5; Ibrahim, 2012, p. 44).

Within Iraqi Arabic phonology, there are 39 phonemes: 8 monophthongal vowels and 31 consonants. There are 3 short vowels /i, u, a/, 5 long vowels /i:, ee, a:, o:, u:/, 12 voiceless consonants and 19 voiced ones. They are /p, b, f, $\Theta, D, S, s, T, t$, č, x, ǵ, h, H, t, k, g, q, ?, j, d, 9, m, n, l, r, w, y/. The voiceless bilabial plosive /p/ is deleted in the phonemic inventory of Nasiriya Iraqi Arabic since it has not been used by the Nasiriya Iraqi people (Abdul-Sattar, 2015, p. 10).

Concerning the syllables, there are 10 possible ones: /cv, cvv, cvc, ccvv, ccvc, cvcc, cvvc, cvvcc, ccvvc, ccvcc/. According to Ghalib (1984, p. 18), the first seven syllables are often used rather than the last three ones which are rarely used. They occur in few words. Most of those words are not originally Arabic. the eleventh syllable which is ccv, as in: tHassan "he got well" (Abdul- Sattar, 1989, pp. 111-112).

\subsection{Description of Arabic Consonants}

The thirty one Arabic consonants can be described in terms of consonantal features which are voicing, place and manner of articulation. Emphatic and non-emphatic consonants (or velarized and non- velarized) can be referred to as well. The emphatic consonants which are /S, ş, T, ţ/ are distinguished from the non-emphatic ones/s, d, D, t/ by iTbaq 'lidding' or 'tafxiim' (emphasis).

Emphatic consonants are produced when the muscles of the pharynx are contracted; the tongue back is raised towards the palate; and the lips are protruded. In addition to those four consonants, there is another one which exists in a very restricted context like the divine name 'السَّ' /1/ (Khalil, 1999, p. 15).

The Arabic back consonants are six: Four are fricatives and two are stops: $/ \mathrm{x}, \mathrm{g} /$ are velar fricatives. They are articulated with the back of the tongue almost touching the soft palate (velum).

/9, $\mathrm{H} /$ are pharyngeal fricatives. /H/ is voiceless while /9/ is voiced. Their production occurs in the pharynx. When they are articulated, the muscles in the pharynx are tensed up.

Another consonant is $/ \mathrm{h} /$ which is the glottal fricative which is voiceless. Its production occurs in the larynx. It occurs in all positions (initially, medially, and finally).

In Arabic, $/ \mathrm{r} /$ is trilled which is repeatedly produced.

$/ 1 /$ is a common consonant. English and Arabic are different in the rules of light-dark- phone distribution.

The English /p, v, g, t $f, 3, \mathrm{n} /$ have no counterparts in standard Arabic (but in Nasiriya Iraqi Arabic, /g and t $\mathrm{f} /$ are found). So, they are called English- restricted consonants. But these Arabic consonants /T, H, S, ş, ț, ?, D, q, 9, ǵ, $\mathrm{x} /$ have no counterparts in English, so they are known as Arabic -restricted consonants (Al-khuli, 1999). 


\subsection{Phonetic Processes}

Phonetic phenomena (assimilation, elision, emphasis 'tafxiim', gemination 'tašdiid') were first studied as part of the old Arab grammarians' grammar, but they did not discuss those linguistic phenomena. This is not because of their unawareness of their existence in the language but the fact is that they considered the sound segments as the vital carriers of intelligibility in oral communication and the suprasegmental features were of marginal significance. The phonetic processes to be discussed in this section are only those which are available in our children's speech.

\section{a. Sound shift (Phonemic substitution):}

Sound shift is a phonetic process that refers to the replacement of one sound segment by another in a certain context. The process of substitution which occurs in the structural context is known as "substitution frame" (Crystal, 2003a, p. 444).

In the typical speech, a number of types of phonetic substitution can be shown. They are: backing in which front sound segments are replaced by back ones; gliding in which glides $/ \mathrm{w}, \mathrm{y} /$ are substituted by liquids $/ 1, \mathrm{r} /$; stopping which occurs when fricatives /f, v, s, z, $\Theta, \partial, \int, 3, \mathrm{~h} /$ or affricates $/ \mathrm{f}$, dz/ are replaced by stops /p, t, b, d, k, g/; and vocalization in which liquids are replaced by vowels (Yeh, 2011, p. 1).

Those processes are usually found in the performance of typically developing children 2-4 years old (Walliamson, 2014).

\section{b. Metathesis}

Metathesis refers to changing the order of successive sounds (Matthews, 2007, p. 244). An interchange of segments is allowed by phonetic rules. For example, ask is pronounced as /aks/ (Hyman, 1975, pp. 14-15). It is the change in the normal sequence of elements in a sentence. Those elements can be sounds, syllables, words or other units. Such a process can be noticed in everyday speech and even it is regarded as a feature observed in language history, as in: hros in Old English which became horse in Modern English (Crystal, 1992, p. 249).

\section{c. Assimilation}

Assimilation is a process by which adjacent sounds become similar to each other by affecting each other. It commonly exists in rapid speech and some in all spoken styles. Three types of assimilation are found: 1 . anticipatory or regressive in which the following sound affects the preceding one: ten balloons /tem/; 2 . progressive: the preceding sound influences the following one: bridge score: the second word will be pronounced as $/ \mathrm{fko}: / ; 3$. coalescence: it is a reciprocal effect: two sounds assimilate to produce a new segment: won't she $/ \mathrm{t} /$ and $/ \mathrm{J} / \rightarrow / \mathrm{t} /$ (Crystal, 2003a, p. 247 and Frawley, 2003, p. 320).

But there are other two main types of assimilation which are historical and contextual. The historical type means that assimilation occurs during the development of a language and by which a word which was pronounced in a certain way came to be pronounced in another way, for example, ant $/ \mathrm{n} /$ was $/ \mathrm{m} /$ which was written as amete and amte /'am $\partial \mathrm{t} \partial /$. in the $15^{\text {th }}$ century, the change from $/ \mathrm{m} /$ into $/ \mathrm{n} /$ appeared (Jones, 1969 , p. 218).

\section{d. Elision}

Elision is a process of losing a vowel at the end of the word, or a vowel before another vowel that follows it at the beginning of a word (Matthews, 2007, p. 119).

When someone's speech becomes quick, some sounds are dropped. In informal speech, vowels in the weak syllables are elided. It is unusual to hear the vowels in the first syllables of the following words: police, correct, etc. /p'lice/. Consonants in the clusters are dropped to simplify the process of speaking. It is difficult to pronounce three consonants altogether at the end of the words: acts of parliament /aks/. Sometimes the whole syllable may be elided when the same consonant is repeated: British pronunciations of library and particularly /laibri: potikjli:/. Or words can be dropped when they occur before consonants: cup o' tea, gonna (going on), etc (Crystal, 2003a, p. 247).

According to Al-Hilfy (2014, p. 60), elision is of interest to old Arab grammarians. It is one of the most important aspects of the Quranic text. For example, two terms are interchangeably used by Sibaweyh which are alHaDif, al?işmar.

In Iraqi Arabic, there are two types of elision which are historical and contextual. Within historical elision, there are two sub-types: phonetic, morphological and syntactic. Phonetically, words: /Tju:r/ (birds); /jdirsu:n/ (they are studying): The short vowels of the first unstressed syllables are dropped. Consonantal segments can also be 
elided: /sbu:9/ (week) for /?usbu:9/; in the morphological and syntactic processes, both consonants and vowels can be dropped: /bi:di/ (with my hand) for /b?i:di/ (Ibrahim, 2012, pp. 45-6).

Contextual elision can be observed in the expressions: /Hamdilla waşşikir/ (thanks and appreciation for God) in which the short vowel /u/ is omitted in the word /al Hamdu/ (thanks) (ibid, p. 48).

e. Gemination

Gemination (tašdiid) refers to the lengthening of Arabic consonants, like the vowels. The consonant can be doubled without an insertion of a vowel. Any consonant can be geminated, especially in the medial position of the word. In Arabic writing, the geminated consonant is referred to by the sign () (šadda or tašdiid) (Ghalib, 1984, p. 27).

"Geminate consonants in Arabic were, and still are, generally orthographically represented with one letter only. It was Al-Khalil who was credited with the introduction of this sign which was merely an looped / $/$ / sound derived from the word 'tafdiid itself". This new sign was important to be introduced to stop any confusion with corresponding words that contain single consonants because there is a distinctive difference between single and geminate consonants in Arabic. For example, /kasara/ (he broke); /kassara/ (he smashed) (ibid).

In Arabic, the sign ( $)$ is used to express that process, for example, "ر means there are three consonants $(\rho, \rho)$ while in English, it is a term which is used in phonetics and phonology to represent two identical adjacent segments of a sound in a single morpheme: happy. Those two sounds can be considered as a long consonant, it is written as two subsequent consonants but phonetically transcribed as one consonant (Crystal, 2003a, pp. 196-7).

f. Nasalization

Nasals $/ \mathrm{m}, \mathrm{n}, \mathrm{\eta} /$ are pronounced when the soft palate is lowered to allow an audible escape of air through the nose. Other consonants and all vowels can be nasalized by being followed by one of the nasals. Its symbol is $/ \sim /$ (Jones, 1973, p. 123). Nasals become voiceless when they follow/s/ in small, snooze. When a plosive is followed by one of the nasals, it will be released through the nose instead of the mouth and the resulting auditory effect is one nasal plosion, so sudden /s $\Lambda \mathrm{dn} /$ rather than /s $\mathrm{d} \partial \mathrm{n} /$ (Crystal, 2003b, pp. 307-8).

g. emphasis (tafxiim)

Emphasis (tafxiim) 'mofaxxama' or 'tafxim' is used more frequently than 'musta9liya' in treatises on Quranic recitation 'tajwiid'. The contrast between 'musta9liya' or 'mufaxxama' and munxafiţa' is rendered by many modern phoneticians as 'emphatic' vs. 'non-emphatic' speech sounds (Bakalla, 2017).

\section{Methodology and Data Collection}

The technique of data collection adopted in this study is based on a number of tapes recorded for the children, and this linguistic study is mainly phonetic and the approach to data consists of the establishment of inductive generalizations from the analysis of the children's language.

The data (see Appendix A) needed for this study has been collected from the speech of the authors' three male children aged two, three and five years at the time of starting recording the data respectively. They live in the same house. Their dialect is Nasiriya Iraqi Arabic. The period of collecting the data lasted for 4 years.

The words which are said by the children are described first in terms of the consonantal features (voicing, place and manner) and then the explanations for each are given.

Most of Nasiriya Iraqi Arabic phonemes (Appendix B) are available in Standard Arabic except /č/; /v/ is neither available in the first nor in the second but it is produced by the informants as a part of the sound shift. Nasiriya dialect is used by the people who live in Nasiriya city and its surroundings, south of Iraq. It is distinguished from other dialects in Iraq by its phonetic, lexical and syntactic features.

\section{Data Analysis and Discussion}

The results of our study can be summarized in the following phonetic rules discovered by the authors as every child in every stage of acquisition is following his interim grammar. The informants' speech is characterized of many changes which are mostly consonantal rather than vocalic. Those changes reflect some phonetic processed like sound shift and metathesis in addition to other phonetic processes. The consonants pronounced can be voiceless and voiced; place of articulation: post-velar, palatal, glottal, dental, bilabial, labio-dental, pharyngeal, nasalized $/ \mathrm{r} /$ and mufaxam $/ 1 /$; in terms of manner of articulation: stop, affricate, nasal, fricative, flap, and lateral (see Appendix B in which every phonetic rule is provided with a number of words in addition to what is available in the following tables): 
Table 1. Statement of rules of change

\begin{tabular}{|c|c|c|}
\hline Original sounds & Changed sounds & Examples with meanings \\
\hline $\begin{array}{l}/ \mathrm{k} /, / \mathrm{g} /(\text { voiceless and voiced velar } \\
\text { stops) }\end{array}$ & $\begin{array}{l}\rightarrow / \mathrm{q} / \text { (voiceless post-velar stop) } \\
\rightarrow / \mathrm{c} / \text { (voiceless palatal affricate) } \\
\rightarrow / \mathrm{h} /(\text { voiceless glottal spirant }) \\
\rightarrow / \mathrm{d} /(\text { voiced dental stop }) \\
\rightarrow / \mathrm{H} /(\text { voiceless pharyngeal spirant }): \\
\rightarrow / \mathrm{t} /\end{array}$ & $\begin{array}{l}\text { 9illaga } \rightarrow \text { 9ilaqa: carrier } \\
\text { glas } \rightarrow \text { čač (a cup) } \\
\text { killiš } \rightarrow \text { hilliš (very) } \\
\text { ig9id } \rightarrow \text { id9id (sit down) } \\
\text { agiH } \rightarrow \text { aHiH (I'm coughing) } \\
\text { killah } \rightarrow \text { tillah (all of it) }\end{array}$ \\
\hline 2. /l/ (voiced lateral alveolar) & $\begin{array}{l}\rightarrow / \mathrm{q} / \\
\rightarrow / \mathrm{n} /(\text { voiced dental nasal }) \\
\rightarrow \text { mufaxam } / 1 /\end{array}$ & $\begin{array}{l}\text { akil } \rightarrow \text { aqiq (I'm eating) } \\
\text { yalla } \rightarrow \text { yanna (let's do it) } \\
\text { xala } \rightarrow \text { hala (my aunt) }\end{array}$ \\
\hline $\begin{array}{l}\text { 3. / T/ (voiced dental emphatic } \\
\text { stop) }\end{array}$ & $\begin{array}{l}\rightarrow / \mathrm{t} /(\text { voiceless dental stop }) \\
\rightarrow / \mathrm{d} / \\
\rightarrow / \check{\mathrm{c}} /\end{array}$ & $\begin{array}{l}\text { aTykum } \rightarrow \text { atyqum (I give you) } \\
\text { inTiniyaha } \rightarrow \text { idiniyaha (give it to me) } \\
\text { yiTašir } \rightarrow \text { yičačir (He is putting something here and there) }\end{array}$ \\
\hline 4. /s/ (voiceless dental spirant) & $\rightarrow / \check{\mathrm{c}} /$ & isma9 $\rightarrow$ ičma9 (listen) \\
\hline 5./r/ (voiced alveolar flap) & $\begin{array}{l}\rightarrow \text { mufaxam } / \mathrm{l} / \\
\rightarrow \text { nasalized } / \mathrm{r} / \\
\rightarrow / \mathrm{h} / \\
\rightarrow / \mathrm{n} /\end{array}$ & $\begin{array}{l}\text { Hibir } \rightarrow \text { Hibil (ink) } \\
\text { halmara } \rightarrow \text { halmara (this time) } \\
\text { rijly } \rightarrow \text { hijly (my leg) } \\
\text { doraymon } \rightarrow \text { donaymon (a name of a cat) }\end{array}$ \\
\hline 6. /šs/ (voiceless palatal spirant) & $\begin{array}{l}\rightarrow / \check{\mathrm{c}} / \\
\rightarrow / \mathrm{h} /\end{array}$ & $\begin{array}{l}\text { yišrab } \rightarrow \text { yičrab (He is drinking) } \\
\text { šakar } \rightarrow \text { hačal (mufaxam) (sugar) }\end{array}$ \\
\hline 7. $/ \mathrm{x} /$ & $\rightarrow / \mathrm{h} /$ & axalyh $\rightarrow$ ahalyh (I put it somewhere) \\
\hline $8 . / \mathrm{j} /$ & $\rightarrow / \mathrm{h} /$ & jizar $\rightarrow$ hačal (carrot) with a vocalic change. \\
\hline 9. /S/ & $\rightarrow / \check{c} /$ & muSaS $\rightarrow$ mučač: a piece of sweet \\
\hline $\begin{array}{l}\text { 10. /ţ/ (voiced dental emphatic } \\
\text { stop) }\end{array}$ & $\begin{array}{l}\rightarrow / \mathrm{v} / \text { voiced labio-dental fricative } \\
\rightarrow / \mathrm{h} / \\
\rightarrow / \mathrm{t} /\end{array}$ & $\begin{array}{l}\text { Hufața } \rightarrow \text { Hufava (diaper) } \\
\text { țalmah } \rightarrow \text { halmah (darkness) } \\
\text { muntaţar } \rightarrow \text { mutatal (a name of a person) }\end{array}$ \\
\hline $\begin{array}{l}\text { 11. /ş/ voiced interdental emphatic } \\
\text { spirant }\end{array}$ & $\begin{array}{l}\rightarrow / \mathrm{v} / \\
\rightarrow / \mathrm{h} / \\
\rightarrow / \mathrm{d} / \\
\rightarrow / \mathrm{q} /\end{array}$ & $\begin{array}{l}\text { abyaş } \rightarrow \text { abyav (white) } \\
\text { aşurbah } \rightarrow \text { ahubah (I beat him) } \\
\text { şowah } \rightarrow \text { dowah (light) } \\
\text { axşar } \rightarrow \text { ahqar (green) }\end{array}$ \\
\hline 12. /z/ voiced dental spirant & $\rightarrow / \mathrm{c} /$ & tilfiziyon $\rightarrow$ tilfičiyon $(\mathrm{TV})$ \\
\hline 13. /ǵ/ voiceless velar spirant & $\begin{array}{l}\rightarrow / \mathrm{h} / \\
\rightarrow / ? / \\
\rightarrow / 9 /\end{array}$ & $\begin{array}{l}\text { ǵurfah } \rightarrow \text { hurfah (room) } \\
\text { yštuǵul } \rightarrow \text { yutu? } 1 \text { (he is working) } \\
\text { baǵdad } \rightarrow \text { ba9dad (name of the city) }\end{array}$ \\
\hline 14. /D/ (voiced interdental spirant & $\begin{array}{l}\rightarrow / \mathrm{h} / \\
\rightarrow / \mathrm{d} /\end{array}$ & $\begin{array}{l}\text { aDibah } \rightarrow \text { ahibah: I throw it; } \\
\text { (Dyč } \rightarrow \text { dyč: This is the thing }\end{array}$ \\
\hline $\begin{array}{l}15 . / \Theta / \text { (voiceless interdental } \\
\text { spirant) }\end{array}$ & $\begin{array}{l}\rightarrow / \mathrm{t} / \\
\rightarrow / \mathrm{h} /\end{array}$ & $\begin{array}{l}\text { Oxina } \rightarrow \text { thina (thick) } \\
\text { iӨniin } \rightarrow \text { ihniin (two) }\end{array}$ \\
\hline $\begin{array}{l}\text { 16. /w/ (high back rounded } \\
\text { semi-vowel) }\end{array}$ & $\rightarrow / \mathrm{h} /$ & wyna $\rightarrow$ hyna (Where is he?) \\
\hline $\begin{array}{l}17 . / \mathrm{b} / \\
18 . / \mathrm{q} /\end{array}$ & $\begin{array}{l}\rightarrow / \mathrm{f} / \\
\rightarrow / ? /\end{array}$ & $\begin{array}{l}\text { bunduq } \rightarrow \text { funduq (a piece of food) } \\
\text { qalam } \rightarrow \text { ?alam (pencil) }\end{array}$ \\
\hline
\end{tabular}

Table 2. The processes which occur in the informants' speech

\begin{tabular}{|c|c|}
\hline The Process Type & Examples \\
\hline 1. Saying words with a total change & Faşouly $\rightarrow$ Batouqy (a name of a child) \\
\hline 2. Saying words with elision & barda $\rightarrow$ bada (curtain) \\
\hline 3. Elision accompanied with one or more sound shifts & mandar $\rightarrow$ madar (nasalized r) (pillow) \\
\hline 4. Saying words with assimilation & Sidiq $\rightarrow$ diqiq (really) \\
\hline 5. A sound shift accompanied with metathesis & mutanazah $\rightarrow$ muntačah (park) \\
\hline 6. Two or more changes in the same word & burkan $\rightarrow$ bulqan (volcano) \\
\hline $\begin{array}{l}\text { 7. One sound in the same word can change twice, i.e. with two } \\
\text { allophones. }\end{array}$ & şowah $\rightarrow$ dowah, howah (light) \\
\hline 8. A change of a half of a word occurs & ?istiqbal $\rightarrow$ hibal (reception room) \\
\hline $\begin{array}{l}\text { No change in the middle of the word but the change is in the first and } \\
\text { last parts. }\end{array}$ & rimot $\rightarrow$ himon (remote control) \\
\hline $\begin{array}{l}\text { 9. Changes occur in the same word without being subject to any of } \\
\text { the above rules. }\end{array}$ & jwariib $\rightarrow$ jlaliib (socks) \\
\hline $\begin{array}{l}\text { 10. More than one process can be found like metathesis, sound shift, } \\
\text { and addition of a sound. }\end{array}$ & ma?axiD $\rightarrow$ mahadid (I do not take it) \\
\hline 11. Gemination can be found with or without elision. & bidayah $\rightarrow$ baddayah (beginning) \\
\hline 12. In some words there is no change at all. & 9indič $\rightarrow$ iddič (You have it) with elision fiil (elephant) \\
\hline 13. There are many words which include metathesis in their speech. & ta9ban $\rightarrow$ tab9an (tired) \\
\hline
\end{tabular}




\section{Conclusions}

This case study arrives at the following:

1. This study is in contrast with Younis (2008) in that it is difficult here for the informants to produce consonants which are fricatives /s, š, z, g, D, $\Theta /$; two stops /k, g/; and one affricate /j/ in terms of manner of articulation; and velar, dental, palatal, interdental in terms of place of articulation. But they are able to pronounce three fricatives easily /f, h, H/; stops /?, t, q, b/; and nasals /m, n/ which are labio-dentals, glottals, dentals, bilabials, post-velars, pharyngeal in terms of place of articulation.

2. It is easy for our children informants to use /q/ (voiceless post-velar stop) instead of many consonants but it is difficult for many Iraqi Nassiriyah children to pronounce it.

3. The informants tend to use /č, $v /$ in their speech although they do not exist in Standard Arabic.

4. The informants are unable to pronounce emphatic consonants. Instead of $/ \mathrm{S} /$, they utter $\mathrm{s}$; instead of $/ \mathrm{T} /$, they pronounce $/ \mathrm{t} /$; instead of $/ \mathrm{t}$, ş /, they utter $/ \mathrm{v} / ; / \mathrm{D} /$ is pronounced as $/ \mathrm{d} / ; / \mathrm{x} /$ is said as $/ \mathrm{h} /$; and $/ \mathrm{g} /$ is pronounced as /h/.

5. The informants produce /f, ?, t, H, y, h, m, q, b/ without any change.

6. As asserted by Davis (2011, p. 132), according to speech observations, the sound shift and other phonetic processes particularly occur in the word initial positions but in this study, those processes can occur in all word positions: initially, medially and finally.

7. Some consonants in the same word have two allophones.

8. A half of a word not only a consonant or a vowel can change.

9. Sound shift and metathesis can be found in the same word.

10. There can also be metathesis, sound shift and addition of sounds in the same word.

11. According to the rules available in table $(1 \& 2)$, it is clear that the main phonetic processes of the informants' speech are sound shift and metathesis, that is why hypothesis (a) is accepted.

12. It is also clear that elision, assimilation, germination, nasalization, and tafxim are the processes which occur secondarily in the rules available in tables (1\&2). This proves that hypothesis (b) is verified.

13. Assimilation occuring with or without sound shift can be found in some words.

14. All the above processes except metathesis are commonly found in our children of 2-4 ages while metathesis begins at 4 and ends at 6 .

15. Vocalic changes are very few in comparison with the consonantal ones.

16. In the children's speech, there are nazsalized / $\mathrm{r} /$ and mufaxam /1/.

17. In some words, a total change of sounds is found.

18. The original and changed sounds have some features in common like voicing, place of articulation and manner of articulation.

\section{Acknowledgements}

We are highly indebted to our informants, our sons, for making us happy in describing their speech and sometimes in participating with us in repeating some words.

\section{References}

Abdul-Sattar, M.A (1989). A Contrastive Study of Consonant Clusters in Standard English and Iraqi Arabic. Unpublished M.A thesis. University of Basrah.

Al-Hilfy, G. N. (2014). Rhetorical and Phonetic Functions of Elision and Ellipsis in the Quran with some Reference to English. Faculty of Education, Al-Muthanna University.

Alkhuli, M. A. (1999). Comparative Linguistics: English and Arabic. Amman: Alfalah House.

Bakalla, M. H. (2017). Arabic Encyclopedia of Language and Linguistics. Koninklijke Brill NV.

Betti, M. J. (2015). Jokes in Iraq: A Study of Coherence and Cohesion. In Betti \& Igaab (Eds.), Linguistic Studies (pp. 51-67). Diwaniyah: Nippur Publishing.

Crystal, D. (1992). An Encyclopedic Dictionary of Language and Languages. Oxford: Blackwell.

Crystal, D. (2003a). Dictionary of Linguistics and Phonetics (5th ed.). London: Blackwell Publishing LTD. 
Crystal, D. (2003b). The Cambridge Encyclopedia of the English Language (2nd ed.). Cambridge: CUP.

Davis, A. S. (2011). Handbook of Pediatric Neuropsychology. New York: Springer Publishing Company, LLC.

Erwin, W. M. (2004). A Short Reference Grammar of Iraqi Arabic. Washington, D.C.: Georgetown University Press.

Frawley, W. (2003). The International Encyclopedia of Linguistics. Oxford: Oxford University Press.

Ghalib, B. M. (1984). An Experimental Study of Consonantal Gemination in Iraqi Colloquial Arabic. Unpublished PH.D. The University of Leeds.

Greenlee, M., \& Ohala, J. J. (1980). Phonetically Motivated Parallels between Child Phonology and Historical Sound Change. Language Sciences, 2(2), 283-308. https://doi.org/10.1016/S0388-0001(80)80019-2

Hyman, L. M. (1975). Phonology: Theory and Analysis. New York: Holt, Rinehart and Winston.

Ibrahim, M. A. (2012). Sounds Disappearance: The Phonetic Idiosyncrasy of Elision in Iraqi Arabic. Canadian Academy of Oriental and Occidental Culture, 8(5), 44-49.

Igaab, Z. K. (2015). A Contrastive Study of Metathesis in English and Arabic. In Betti \& Igaab (Eds.), Linguistic Studies (pp. 51-67). Diwaniyah: Nippur Publishing.

Ingram, D. (1987). First Language Acquisition: Method, Description and Explanation. Cambridge: Cambridge University Press.

Jasim, T. A., \& Sharhan, K. S. (2013). Phonetic Metathesis in Iraqi Arabic Dialect: A Synchronic Perspective. Journal of College of Languages, 26, 1-24.

Jones, D. (1969). An Outline of English Phonetics. Cambridge: W. Heffer and Sons LTD.

Jones, D. (1973). The pronunciation of English. Cambridge: Cambridge University Press.

Khalil, A. M. (1999). A Contrastive Grammar of English and Arabic. Amman: Jordan Book Centre Company Limited.

Matthews, P. H. (2007). Oxford Concise Dictionary of Linguistics (2nd ed.). Oxford: Oxford University press.

Steinberg, D. D. (1991). Psycholinguistics: Language, Mind and World. New York: Longman Group Limited.

Williamson, G. (2014). Phonetic Processes. Retrieved from http://www.sltinfo.com

Yeh, K. (2011). Common Phonetic processes. Retrieved from http://www.playingwithwords

Younis, U. I. (2008). Substitution in Child Speech. Buhuth Mustaqbaliya, 21, 35-56.

\section{Appendix A}

\section{List of Iraqi Arabic Phonemic Inventory}

1. The Consonants

\begin{tabular}{lll}
\hline Symbol & Description & Example \\
\hline$/ \mathrm{f} /$ & Voiceless labio-dental fricative & fiil (elephant) \\
$/ \mathrm{O} /$ & Voiceless interdental fricative & Oa9lab (fox) \\
$/ \mathrm{D} /$ & Voiced interdental fricative & Dabha (he threw it) \\
$/ \mathrm{S} /$ & Voiceless dental emphatic fricative & Sabur (patience) \\
$/ \mathrm{s} /$ & Voiced interdental emphatic fricative & şabuT (an officer) \\
$/ \mathrm{T} /$ & Voiceless dental emphatic stop & TamaTa (tomato) \\
$/ \mathrm{t} /$ & Voiced dental emphatic stop & ţaal (staying) \\
$/ \mathrm{s} /$ & Voiceless dental fricative & suug (market) \\
$/ \mathrm{z} /$ & Voiced dental fricative & zrar (button) \\
$/ \check{\mathbf{s}} /$ & Voiceless palatal fricative & šmalak (what is wrong with you?) \\
$/ \check{\mathrm{c}} /$ & Voiceless palatal affricate & čaly (bank of the river) \\
$/ \mathrm{x} /$ & Voiceless velar fricative & xubuz (bread) \\
$/ \mathrm{g} /$ & Voiceless velar fricative & grab (crow) \\
$/ \mathrm{h} /$ & Voiceless glottal fricative & hna (here) \\
$/ \mathrm{H} /$ & Voiceless pharyngeal fricative & Hariim (women) \\
$/ \mathrm{b} /$ & Voiced bilabial stop & bab (door) \\
$/ \mathrm{t} /$ & Voiceless dental stop & timman (rice) \\
$/ \mathrm{k} /$ & Voiceless velar stop & ka9ak (cake) \\
\hline
\end{tabular}




\begin{tabular}{lll}
\hline$/ \mathrm{g} /$ & Voiced velar stop & ga9ad (he sat down) \\
$/ \mathrm{q} /$ & Voiceless uvular stop & qadiim (old) \\
$/ ? /$ & Glottal stop & ?amis (yesterday) \\
$\mathrm{j} /$ & Voiced palatal affricate & jamal (beauty) \\
$/ \mathrm{p} /$ & Voiceless bilabial stop & parda (curtain) \\
$/ \mathrm{d} /$ & Voiced dental stop & tdanna (be near by) \\
$/ 9 /$ & Voiced pharyngeal fricative & 9aly (high) \\
$/ \mathrm{m} /$ & Voiced bilabial nasal & minhu (who is it?) \\
$/ \mathrm{n} /$ & Voiced dental nasal & nibaH (barked) \\
$/ \mathrm{l} /$ & Voiced alveolar lateral & limna (gather us) \\
$/ \mathrm{r} /$ & Voiced alveolar flap & ramul (sand) \\
$/ \mathrm{w} /$ & High back rounded semi-vowel & wayyana (with us) \\
$/ \mathrm{y} /$ & High front unrounded semi-vowel & yamta (when) \\
\hline
\end{tabular}

2. The Vowels

\begin{tabular}{lll}
\hline Vowels & Description & Example \\
\hline i & Short half-close front with lip spreading & mi9da (stomach) \\
ii & Long close front with lip spreading & biina (in us) \\
a & Short half -open central neutral & saliim (healthy) \\
aa & Long open- central neutral & saalim (safe) \\
u & Short half -close back rounded & ummii (my mother) \\
uu & Long close back rounded & 9uud (stick) \\
oo & Long half-close to half- open back rounded & tilifoon (telephone) \\
\hline
\end{tabular}

Note. They are taken from Betti (2015, pp. 223-224) and Greenlee (1980, pp. 3-4).

\section{Appendix B}

\section{The Data Collected from the Children}

1. tiDakryn $\rightarrow$ tiDaqryn: Do you remember?;

$$
\begin{aligned}
& \text { idak } \rightarrow \text { idaq: your hand; } \\
& \text { adyk } \rightarrow \text { adyq (I give you); } \\
& \text { kyka } \rightarrow \text { qyqa (cake); } \\
& \text { goom } \rightarrow \text { qoom (stand up); } \\
& \text { biskit } \rightarrow \text { bičičt (biscuit); } \\
& \text { alkitab } \rightarrow \text { alhitab (the book); } \\
& \text { kafy } \rightarrow \text { hafy (enough); } \\
& \text { kabira } \rightarrow \text { habira (big); } \\
& \text { kantoor } \rightarrow \text { hantoor (cupboard); } \\
& \text { agilla } \rightarrow \text { adilla (I told him); }
\end{aligned}
$$

2. Flona $\rightarrow$ Fnona: a name of a person;

laymon $\rightarrow$ naymon (lemon);

laHma $\rightarrow$ naHma (meat);

3. Tabla $\rightarrow$ tabla (table)

Toba $\rightarrow$ doba: ball;

muTy $\rightarrow$ mudy: donkey;

Tyn $\rightarrow$ dyn (mud); HayT $\rightarrow$ Hayd (wall);

baTny $\rightarrow$ bačny (my abdomen); 
4. 9abas $\rightarrow$ 9abač: a name of a person;

ashal $\rightarrow$ ačhal: easier than;

hasa $\rightarrow$ hača (now);

simač $\rightarrow$ čimač (fish);

asad $\rightarrow$ ačad (lion);

aswad $\rightarrow$ ?ačwad (black)

5. far $\rightarrow$ fal: mouse;

aHmar $\rightarrow$ aHmal:red;

rooba $\rightarrow$ looba (yogurt);

nimir $\rightarrow$ nimil (tiger);

bačir $\rightarrow$ bačil (tomorrow);

a9ruf $\rightarrow$ a9luf (I know);

yiriid $\rightarrow$ yiliid (He wants something);

brasy $\rightarrow$ bhačy (by my head);

6. imšy $\rightarrow$ imčy: walk;

šiliiny $\rightarrow$ čiliiny: carry me;

širiir $\rightarrow$ čiliil (vicious);

liiš $\rightarrow$ liič (why?);

šofy $\rightarrow$ hofy: Look;

7. mxabal $\rightarrow$ mhabal: He is crazy;

xiyar $\rightarrow$ hiyar (cucumber);

8. jozy $\rightarrow$ hočy (colour);

9. Sot $\rightarrow$ čot: voice;

buSal $\rightarrow$ bučal:onions;

$\mathrm{SaHib} \rightarrow$ čaHib (friend);

Sadiq $\rightarrow$ čadiq (honest);

Suqoor $\rightarrow$ čuqoor (eagles);

11. 9aşaş $\rightarrow$ 9avav: one who bites someone;

bişa $\rightarrow$ biva (egg);

arş $\rightarrow$ arv (ground);

maHfaşa $\rightarrow$ maHfava (suitcase),

aǵraşy $\rightarrow$ aǵraşy (my things)

şammata $\rightarrow$ hammadha (She kept it away); 
12. zbala $\rightarrow$ čbala: rubbish;

azraq $\rightarrow$ ačlaq (blue);

ziin $\rightarrow$ čiin $(\mathrm{OK})$;

Hamzah $\rightarrow$ Hamčah (a name of a person);

13. yǵasil $\rightarrow$ yhačil (He is cleaning his hands);

14. Dubana $\rightarrow$ hubana (insect);

Diib $\rightarrow$ diib (wolf);

15. $\Theta l a \Theta a \rightarrow$ tlata (three);

17. ǵabah $\rightarrow$ hafah (forest);

19. Sǵayron $\rightarrow$ ?anon (a little boy);

? ištryly $\rightarrow$ hanyny (buy something for me);

naţarah $\rightarrow$ harrarah (nasalized) (glasses);

klinsayah $\rightarrow$ hatayah (Kleenex);

20. 9indič $\rightarrow$ 9idič: You have it;

(?inTyniyaha $\rightarrow$ ?idyniyaha: give it to me;

bardan $\rightarrow$ badan: I feel cold;

jarboo9 $\rightarrow$ jaboo9: lizard;

burtaqaly $\rightarrow$ butaqaly:orange;

aktub $\rightarrow$ atub (I'm writing);

alwan $\rightarrow$ awan (colours);

arnab $\rightarrow$ anab (rabbit);

alibsa $\rightarrow$ abisa (I'm wearing it);

allah wayak $\rightarrow$ awyak (good bye);

trab $\rightarrow$ tab (sand);

wardy $\rightarrow$ wady (pink);

kursy $\rightarrow$ kučy (chair);

inzil $\rightarrow$ ičil (go down);

aSdiqaa? $\rightarrow$ adiqaa? (friends);

21. agdar $\rightarrow$ adal (mufaxam) (I can);

yixarmiš $\rightarrow$ yihamič (scratch);

aštiry $\rightarrow$ atily (I'm buying something);

?akӨar $\rightarrow$ atar (more);

nastalah $\rightarrow$ hatala (a piece of sweets); 
22. musadas $\rightarrow$ mučačač: gun;

marwaHa $\rightarrow$ maHmaHa:fan;

9iTašit $\rightarrow$ 9ičatit (Ifelt thirsty);

maTbax $\rightarrow$ maxmax (kitchen);

tost $\rightarrow$ čoč (a type of food);

23. yqbal $\rightarrow$ hybal: he accepts;

ligaha $\rightarrow$ hilaha (he found it);

24. inkisrat $\rightarrow$ inhičrat: it was broken;

aksir $\rightarrow$ ahčil (mufaxam) I'm breaking it);

zarafa $\rightarrow$ čalafa: giraffe;

boorag $\rightarrow$ boolaq: a piece of food;

šaT $\rightarrow$ čad: river;

kilhin $\rightarrow$ hinhin: all of it;

axalSa $\rightarrow$ ahalča (I finish it);

šari9 $\rightarrow$ čali9 (street);

xubiz $\rightarrow$ hubič (bread);

ša9ar $\rightarrow$ ča9al(mufaxam) (hair);

šamsiyah $\rightarrow$ čamčiyah (umbrella);

cocopops $\rightarrow$ qoqobobč (a type of food);

kiliš $\rightarrow$ hilič (very);

yxalony $\rightarrow$ yhalony (they let me do it);

xamsa $\rightarrow$ hamča (five);

25. baǵdad $\rightarrow$ ba9dad, ba?dad;

30. may: water;

iftaHiha: open it;

Hamamah: penguin;

$\mathrm{bab} \rightarrow$ bab (door);

Haywanat (animals).

31. muka9abah $\rightarrow$ mukaba9ah (cubes);

9ailah $\rightarrow$ a9ilah (family);

šab9an $\rightarrow$ ša9ban (full up);

baqarah $\rightarrow$ qabrah (cow);

lisan $\rightarrow$ silan (tongue);

kahraba? $\rightarrow$ karhaba? (electricity);

la9ibiin $\rightarrow$ labi9iin (players);

Өaniyah $\rightarrow$ Oaynah (second);

labtob $\rightarrow$ latbob (laptop); 


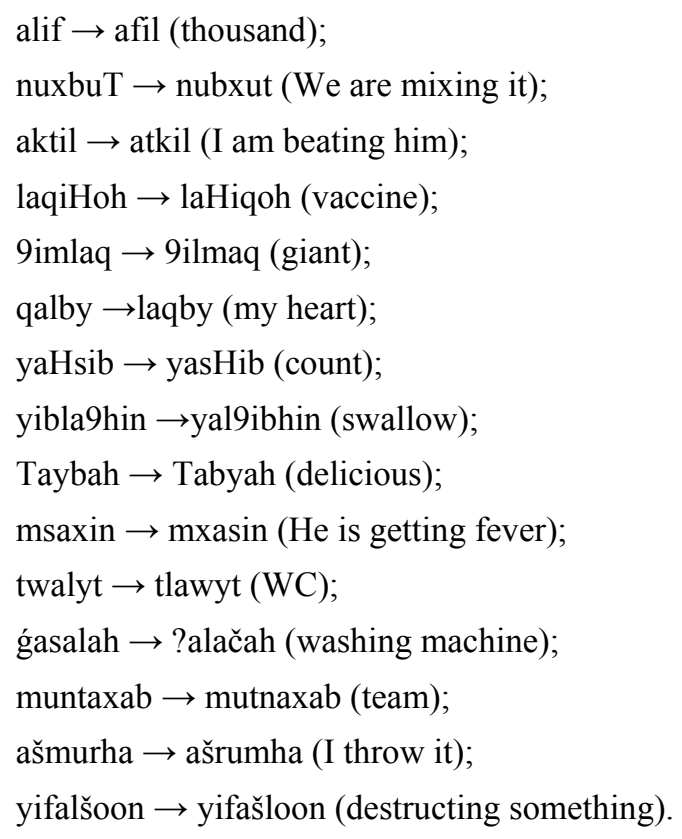

\section{Copyrights}

Copyright for this article is retained by the author, with first publication rights granted to the journal.

This is an open-access article distributed under the terms and conditions of the Creative Commons Attribution license (http://creativecommons.org/licenses/by/4.0/). 